\title{
Undetected $\alpha$ Klotho in serum is associated with the most aggressive phenotype of breast cancer
}

\author{
BRUNA CRISTINA BORGES ${ }^{1 *}$, PEDRO AUGUSTO DO AMARAL ${ }^{1 *}$, LUIZ RICARDO SOLDI $^{1}$, \\ VICTOR LUIGI COSTA SILVA ${ }^{1}$, FERNANDA CARVALHO DE SOUZA ${ }^{1}$, FELIPE ANDRÉS CORDEIRO DA LUZ ${ }^{1,2}$, \\ ROGÉRIO AGENOR DE ARAÚJO ${ }^{2}$ and MARCELO JOSÉ BARBOSA SILVA ${ }^{1}$ \\ ${ }^{1}$ Departamento de Imunologia, Instituto de Ciências Biomédicas, Universidade Federal de Uberlândia; \\ ${ }^{2}$ Núcleo de Prevenção, Pesquisa e Projeto de Câncer, Hospital do Câncer, Uberlândia, MG 38400-902, Brazil
}

Received May 18, 2021; Accepted December 9, 2021

DOI: $10.3892 / \mathrm{mco} .2022 .2526$

\begin{abstract}
Klotho, a cellular anti-senescence protein, is related to antitumor actions, growth regulation, proliferation and invasiveness in several types of tumor, including breast cancer. The present study aimed to analyze the serum levels of $\alpha$ Klotho in patients with breast cancer according to histopathological and immunohistochemical variables. A total of 74 patients and 60 healthy controls were recruited. Peripheral blood samples were collected and serum levels were assessed by sandwich ELISA. Clinical and diagnostic data were obtained from medical records and databases of the Clinical Hospital of the Federal University of Uberlândia (Uberlândia, Brazil). The results indicated no difference in the levels of $\alpha$ Klotho between patients and controls $(\mathrm{P}=0.068)$; however, the number of patients with breast cancer with undetectable $\alpha$ Klotho was high $(n=52)$. Thus, the variables that were associated with the lowest survival rates were analyzed, relating them to undetectable $\alpha$ Klotho. Among cases of metastatic tumors or tumors with poor differentiation, positive lymph node status and triple-negative status, patients with undetectable $\alpha$ Klotho predominated and had unfavorable overall survival. Due to the significant results obtained in triple-negative patients, an in vitro analysis was performed to determine whether estrogen receptors (ERs) have a role in $\alpha$ Klotho production. Treatment of MCF-7 cells with ER agonists, estradiol (E2) and diarylpropionitrile (DPN), resulted in increases in $\alpha$ Klotho expression and supernatant levels of both agonists, demonstrating a direct association between the ER and Klotho production; of note, the ER $\beta$-specific agonist DPN tripled $\alpha$ Klotho expression
\end{abstract}

Correspondence to: Dr Bruna Cristina Borges, Departamento de Imunologia, Instituto de Ciências Biomédicas, Universidade Federal de Uberlândia, Sala 210, Bloco 2B, Rua Piauí, Campus Umuarama, Uberlândia, MG 38400-902, Brazil

E-mail: brunacb90@gmail.com

${ }^{*}$ Contributed equally

Key words: $\alpha$ Klotho, breast cancer, ELISA, prognosis when compared to $\mathrm{E} 2(\mathrm{P}=0.078)$. These data suggested that undetectable $\alpha$ Klotho in the serum of patients with breast cancer is related to unfavorable histopathological variables and poor prognosis and ERs possibly have an important role in maintaining adequate quantities of $\alpha$ Klotho.

\section{Introduction}

Klotho is a single-pass, type 1 membrane protein named after Clotho, one of the Three Fates who spins the thread of life from ancient mythology, and is involved in the regulation of aging and longevity (1). Kuro-o et al (2) discovered that mice with a Klotho mutation presented with several complications related to premature aging, revealing cellular anti-senescence actions (3). Klotho is present in several tissue types, such as that of the kidneys, parathyroid glands, choroid plexus and arteries, where it forms an essential constitutive receptor complex with fibroblast growth factor (FGF) receptors, generating affinity between these receptors and their ligands $(2,4,5)$. Among all functions described for Klotho, its renal functions are the most prominent, where it acts upon ion homeostasis, such as that of phosphate ions, and is a co-receptor of FGF-23 $(6,7)$. The following three isoforms have been detected: $\alpha$ Klotho, $\beta$ Klotho and $\gamma$ Kotho, with $\alpha$ Klotho being the most abundant and responsible for most of the anti-aging actions described (8-10).

Besides being a constituent of the plasma membrane, Klotho may be cleaved by the membrane-anchored metallopeptidases ADAM10 and ADAM17 to generate a secreted form of the Klotho protein that is released so that it may act as an autocrine, paracrine or endocrine hormone in blood, urine and cerebrospinal fluid (11-14). Secreted Klotho may also be generated by alternative splicing and by cleavage of the cytoplasmic portion of Klotho, and the actions of both of these remain to be elucidated $(15,16)$. After secretion, Klotho acts in a pleiotropic manner, interacting with several growth factor receptors and ion channels and regulating oxidative stress, thus protecting several organs of acute and chronic diseases related to senescence, such as cancer $(4,7,13,17)$.

Klotho is classified as a tumor suppressor protein due to its involvement in cell growth, proliferation, differentiation and migration, with an impact on survival, and is also related to response to chemotherapy (18-22). Klotho is epigenetically 
silenced in cancer and its importance in cancer-cell growth was demonstrated by in vitro experiments that used soluble Klotho or tumor lineage cells that overexpressed Klotho. All results demonstrated that Klotho expression decreases cancer-cell division $(23,24)$. Klotho has been indicated to act through several signaling pathways, such as FGF, Wnt, p53/p21, TGF- $\beta$ and insulin-like growth factor 1 (IGF-1)/insulin pathways (25-28), and is a determining factor in numerous types of tumor, including lung, kidney, colon, prostate, ovarian, cervical and breast cancer (24,29-34). As an example, Klotho interferes with the IGF-1/insulin signaling pathway, most frequently through its most abundant soluble isoform, $\alpha$ Klotho.

The lack of soluble $\alpha$ Klotho has also been linked to cancer metastasis. The binding of Klotho to the calcium-permeable transient receptor potential canonical 1 channel along with vascular endothelial growth factor 2 strengthens the association between both, helping promote entrance into the cell. Through this interaction, Klotho regulates calcium entrance and activity in endothelial cells. In knockout mice for Klotho, endothelial integrity was diminished and the endothelium became permeable (35). This increased permeability, together with pro-inflammatory molecules that increase the expression of adhesion molecules, facilitates tumor-cell migration through epithelial-mesenchymal transition $(36,37)$. The re-establishment of Klotho expression in culture cells decreases tumor-cell proliferation and induces apoptosis and autophagy $(38,39)$. Due to this, Klotho may be considered an important factor for regulating cellular proliferation and metastasis and it has already been linked to positive prognoses (38-41).

Breast cancer is the second most common cancer type in females and is the second greatest cause of mortality in this population (42-44). Diagnosis, staging and definition of therapy in breast cancer are based on important histopathological parameters, such as tumor size, tumor grade, lymph-node involvement and molecular characteristics, such as the presence of hormonal and growth factor receptors, which determines therapeutic success and may be utilized for relapse prevention $(45,46)$. The TNM classification of malignant tumors is frequently used in the clinic to classify patients and guide treatment protocols (47).

Pathophysiological evidence indicated that tumors use excess levels of serum phosphate for stimulating tumorigenesis; thus, the expression of Klotho may be closely associated with tumorigenesis in certain tissues and organs. However, Klotho may also suppress cell proliferation and metastasis by inhibiting the signaling of growth factors such as IGF-1 and TGF- $\beta$ (48).

$\alpha$ Klotho contains two internal repeats, KL1 and KL2, which, due to the absence of two conserved glutamic acid residues, differentiate this protein from other family I glycosidases. In breast cancer, $\alpha$ Klotho domains have differential activity. In in vitro and in vivo models, KL1 was able to inhibit colony formation by MCF-7 and MDA-MB-231 cells and slow tumor formation in nude mice. In addition, only KL1 interacted with IGF-1 receptor and it inhibited the IGF-1 pathway in these models (49). In triple-negative breast cancer, $\gamma$ Klotho is necessary for cell survival and its depletion leads to constitutive extracellular signal-regulated kinase activation, cell cycle arrest, oxidative stress and apoptosis (50).
Due to the scarcity of information regarding the relationship between $\alpha$ Klotho and histopathological variables in breast cancer, the present study was performed to evaluate the clinical significance of serum $\alpha$ Klotho in patients with breast cancer according to histopathological and immunohistochemical variables.

\section{Materials and methods}

Patients and samples. Blood samples from the patients included in the present study were obtained in partnership with the Center for Cancer Prevention and Research (NUPPEC) in the oncology sector of the Clinical Hospital at the Federal University of Uberlândia (HC-UFU; Uberlândia, Brazil). After selection from September 2015 to August 2017, 134 individuals were included in the present study, of whom 74 patients were diagnosed with breast cancer at a referral hospital for cancer treatment (HC-UFU) and had not received any previous treatment (surgical, radiotherapy or chemotherapy). The control group was composed of healthy family members with matching ages who agreed to participate in the study $(n=60)$ and who had no previous history of cancer. All participants were female. The sample size was estimated by G*Power 3.1.9.7 (https://www. psychologie.hhu.de/arbeitsgruppen/allgemeine-psychologie-undarbeitspsychologie/gpower) open-source software. The effect of size, $\alpha$ error and Power was defined as 0.5, 0.05 and 0.80, respectively.

Peripheral blood samples from the patients and controls were collected by professionals in the research support group (NUPPEC) during the first interview. After blood centrifugation, serum was separated according to a standard protocol and stored at $-80^{\circ} \mathrm{C}$ in the NUPPEC sample bank.

In addition, demographic and clinical data from patients and controls were collected from the NUPPEC database and medical records. Histopathological and immunohistochemical variables including tumor size, histological classification, lymph node status, estrogen receptor (ER) status, progesterone receptor (PgR) status, human epidermal growth factor receptor 2 (HER2) status and Ki67 expression, were obtained from biopsy data registered in the Hospital Information System of HC-UFU.

In an additional analysis, clinical data were utilized to stratify the patients. Using the TNM classification, patients were separated by tumor stage (I-IV). Subsequently, patients were classified according to a molecular subtype of their tumor. This classification was based on the St. Gallen International Consensus of Experts in Breast Cancer (51).

Ethics, consent and permissions. A Term of Consent for use of medical notes and serum samples was signed by each of the participants. Once accepted, participants were informed that their information would be used in secondary studies that were ethically approved by the Plataforma Brasil Research Ethics Committee under technical advice number 38930314.5.0000.5565. The project was submitted and approved via the Triângulo University Center-UNITRI (Uberlândia, Brazil). All information collected was kept confidential by the researchers.

Cell culture. The MCF-7 cell line was purchased from the Cell Bank of Rio de Janeiro. Cells were cultured in RPMI-1640 
medium (Sigma Aldrich; Merck KGaA) containing HEPES, sodium bicarbonate, penicillin/streptomycin and 10\% fetal bovine serum (FBS). The analyses utilized phenol red-free RPMI-1640 medium and 5\% hormone-free FBS (52) (withdrawal made with dextran and activated charcoal). Cells were grown in a humid environment at $37^{\circ} \mathrm{C}$ with $5 \% \mathrm{CO}_{2}$. All assays were performed before cells reached $80 \%$ confluence.

ELISA. Serum-soluble $\alpha$ Klotho and soluble $\alpha$ Klotho in MCF-7 supernatant were measured by ELISA (kit no. DY5334-05; R\&D Systems Europe, Ltd.) according to the manufacturer's protocol. Assays were performed in 96 -well plates. The patient serum was plated in duplicate and the cell supernatant was plated in triplicate. The plate was read at $450 \mathrm{~nm}$ in a GloMax ${ }^{\circledR}$ Discover System (Promega Corporation) and the absorbance was obtained as the optical density.

Reagents and treatments. The non-specific ER agonist estradiol (E2) and the ER $\beta$-specific agonist diarylpropionitrile (DPN) were purchased from Sigma-Aldrich (Merck KGaA). Cells were subjected to $24 \mathrm{~h}$ of hormonal depletion with phenol red-free RPMI-1640 medium and hormone-free 5\% FBS. After $24 \mathrm{~h}$, each group was treated with the respective agonist at a concentration of $10 \mathrm{nM}$. DMSO was used as a vehicle for the drugs (DMSO v/v, 1:1,000). Cells were treated for $48 \mathrm{~h}$ for reverse transcription-quantitative PCR (RT-qPCR) assays and for $72 \mathrm{~h}$ for the proliferation assay.

Total RNA isolation and RT. Total RNA was first extracted using the Total SV RNA Isolation System kit (cat. no. Z3100) in a Maxwell ${ }^{\circledR}$ RSC Instrument (Promega Corporation), and complementary DNA (cDNA) was obtained from total RNA using the GoScript ${ }^{\mathrm{TM}}$ System Reverse Transcription kit (cat. no. A5001; Promega Corporation) in a total reaction mixture volume of $20 \mu \mathrm{l}$, which was performed in a SimpliAmp ${ }^{\mathrm{TM}}$ Thermal Cycler (Thermo Fisher Scientific, Inc.). For this, $5 \mu \mathrm{g}$ of total RNA was used to obtain cDNA. It was initially thermally denatured at $70^{\circ} \mathrm{C}$ for $5 \mathrm{~min}$ and chilled on ice. After centrifugation, RT reaction mix was added and the mix was annealed at $25^{\circ} \mathrm{C}$ for $5 \mathrm{~min}$. The reaction was then incubated at $42^{\circ} \mathrm{C}$ for up to $1 \mathrm{~h}$. RNA and cDNA were quantified with GoScript ${ }^{\mathrm{TM}}$ RNA System and ssDNA System kits (cat. nos. E3310 and E3190; Promega Corporation) using a Quantus ${ }^{\mathrm{TM}}$ Fluorometer (Promega Corporation). All assays were performed according to the manufacturer's protocol.

$q P C R$. The gene expression of proposed targets in the MCF-7 lineage was evaluated by qPCR. Cells were cultured in 48 -well plates, total RNA was isolated, RT was performed and the qPCR reaction was performed with the GoTaq ${ }^{\circledR}$ qPCR Master Mix kit (Promega Corporation) according to the manufacturer's protocol. qPCR conditions were $95^{\circ} \mathrm{C}$ for $2 \mathrm{~min}$, followed by 40 cycles of $95^{\circ} \mathrm{C}$ for $15 \mathrm{sec}$ and $60^{\circ} \mathrm{C}$ for $60 \mathrm{sec}$. The primers used for specific amplification of Klotho were the following: Forward, 5'-GCTCTCAAAGCCCACATACTG-3' and reverse, 5'-GCAGCATAACGATAGAGGCC-3'. Furthermore, $\beta-2$ microglobulin was used as the endogenous gene with the following primers: Forward, 5'-TATCCAGCGTACTCCAAA GA-3' and reverse, 5'-GGATGAAACCCAGACACATAG-3'. Sequences were designed with the Primer Quest ${ }^{\mathrm{TM}}$ tool IDT's and analyzed with BLAST 2.2.29 (53). An efficiency curve was obtained for all primers. A total of $100 \mathrm{ng}$ cDNA was used for a total of 40 cycles per reaction. The reaction parameters were selected according to the manufacturer's protocol. The RNA expression was determined using the $2^{-\Delta \Delta \mathrm{Cq}}$ method (54).

Carboxyfluorescein diacetate succinimidyl ester (CFSE) proliferation assay. After cell treatment, cells were trypsinized, washed with PBS and resuspended in RPMI-1640 phenol red-free medium at a concentration of $5 \times 10^{5}$ cells $/ \mathrm{ml}$. Subsequently, CFSE (Invitrogen; Thermo Fisher Scientific, Inc.) was added to obtain a final concentration of $5 \mu \mathrm{M}$ and cells were incubated for $15 \mathrm{~min}$ at $37^{\circ} \mathrm{C}$ in constant homogenization. Next, cells were washed again with PBS and CFSE decay was evaluated. Analyses were performed by flow cytometry on a CytoFlex (Beckman Coulter).

Statistical analysis. Statistical analysis was performed with the software packages SPSS (version 25 for Windows; IBM Corporation) and GraphPad Prism $8.0^{\circ}$ (GraphPad Software Inc.). Descriptive statistics were used for evaluation of the demographic, clinical and pathological characteristics of patients and data were expressed as n (\%). Fisher's exact test was employed to compare the proportion of categorical variables in tables formatted as $2 \times 2$. For other table formats, the $\chi^{2}$ test was used. In addition, the $\chi^{2}$ goodness of fit test was used to verify whether the proportion of all groups defined by all categorical variables was different from a hypothetical scenario in which all proportions were the same. The Shapiro-Wilk normality test was utilized to determine whether the Klotho serum concentration fit a Gaussian curve. For normal distributions, Levene's test was employed to assess the equality of variance for variables distributed into two or more groups. If the equality of variance was not equal, a Welch-corrected t-test was used. Tukey's test was used as a post-test if equality of variance was assumed and Tamhane's T2 test was employed if equality of variance was not assumed. For non-parametric data, the Mann-Whiney U-test and the Kruskal-Wallis test were used to compare the ranks between two groups. Regardless of the test used, all continuous variables were presented as the mean and standard deviation. The log-rank statistical test was utilized to compare the survival distributions of two or more groups. To evaluate predictors of poor prognosis in breast cancer, all survival curves with a log-rank P-value $<0.05$ were included in a multivariate Cox proportional hazard regression model. Subsequently, the stepwise backward method was employed to construct a final model for variables with $\mathrm{P}<0.10$.

\section{Results}

General characteristics of the participants. A total of 134 subjects females were interviewed for the present study; 74 (55.2\%) patients had breast cancer and 60 (44.8\%) individuals constituted the control group. The proportion of females in these two groups studied was statistically the same $(\mathrm{P}=0.23)$. The mean age did not significantly differ between patients and the control group $(53 \pm 11.3$ and $52.7 \pm 9.6$ years; $\mathrm{P}=0.77)$. Most of the participants were aged 50+ years (55.2\%); more precisely, $50 \%$ of patients and $61.7 \%$ of controls. The binomial test demonstrated that there was no significant difference 
between the number of patients and relatives aged below or above 50 years $(\mathrm{P}=0.22)$. The number of participants that were experiencing menopause $(64.2 \%)$ was significantly different when compared to the premenopausal considering both groups $(35.8 \%, \mathrm{P}<0.001)$. However, the menopausal status was not different when comparing patients with breast cancer $(\mathrm{P}=0.163)$. Of the patients with breast cancer, eight patients $(10.8 \%)$ were undergoing hormone replacement therapy (HRT) and $66(89.2 \%)$ were not $(\mathrm{P}<0.001)$. The data for HRT were not collected from the controls. The distribution of the patients according to body mass index was significantly different $(\mathrm{P}<0.001)$, with the majority in the overweight $(35.1 \%)$ and normal range $(31.3 \%)$, a similar percentage of obese individuals $(26.9 \%)$ as those in the overweight and normal range and the smallest percentage of underweight $(6.7 \%)$ individuals, considering both patients with breast cancer and controls. In the patient group, most subjects were overweight $(40.6 \%)$ and the smallest percentage of subjects was underweight $(8.1 \%, \mathrm{P}=0.001)$. Unhealthy habits such as alcoholism and smoking were also analyzed in the studied population. A significant difference in the presence of these habits was observed when analyzing all participants $(\mathrm{P}<0.001)$, patients $(\mathrm{P}<0.001)$ and controls $(\mathrm{P}<0.001)$. The majority of participants had never consumed alcohol $(57.1 \%)$ and had never smoked (65.4\%). This was similarly observed in the patient group: Most declared that they had never used alcohol (58\%), nor had they ever smoked (61.6\%). The participants were questioned if they had been exposed to second-hand smoke, where the majority affirmed exposure (69.4\%), with the control group having nearly the same proportion $(66.2 \%)$. To evaluate healthy habits, participants were asked if they performed regular physical activity, with the majority replying that they did not $(76.1 \%, \mathrm{P}<0.001)$. The majority of the patient group did not partake in any regular physical activity, either $(87.8 \%$, $\mathrm{P}<0.001$; Table I). Thus, general characteristics such as body mass index, alcoholism, smoking and regular physical activity were not significantly different between patients and controls.

Histological features. In Table II, the distribution of the cases regarding histology, tumor grade, metastatic stage and TNM classification was significantly different between the $\alpha$ Klotho Undetectable and Detectable groups $(\mathrm{P}<0.001,<0.001,<0.001$, $=0.002$ and $=0.002$, respectively). Ductal carcinoma was the most prevalent type $(91.6 \%)$, followed by lobular cases $(8.3 \%)$. Invasive ductal carcinoma was the most common type of breast cancer $(89 \%)$, followed by invasive lobular carcinoma (6.7\%) and ductal carcinoma in situ $(4 \%)(\mathrm{P}<0.001)$. Most of the tumors had a moderate degree of differentiation $(65 \%)$, with initial tumors $(50 \%)$ mostly at stage II $(37.8 \%)$. The proportions of molecular subtypes differed significantly $(\mathrm{P}=0.005)$, with the luminal being the most common (48.6\%), followed by triple-negative $(33.8 \%)$ and HER2-positive (17.6\%). The tumor dimensions ranged from 2 to $5 \mathrm{~cm}$ for $37.8 \%$ of the analyzed cases, followed by those that were $>5 \mathrm{~cm}(24.3 \%)$ and $<2 \mathrm{~cm}$ (14.9\%), while invasive tumors accounted for $23 \%$ of the studied cases; thus, tumor size was a histological feature with a significant difference between groups $(\mathrm{P}=0.005)$. Lymph node metastasis was present in about half $(52.7 \%)$ of the studied participants. Staining for molecular markers demonstrated that the number of patients positive for the
ER did not differ from the number of patients who were ER-negative $(\mathrm{P}=0.81)$. However, patients with progesterone and HER2 receptor differed statistically $(\mathrm{P}=0.03$ and $<0.001$, respectively). The proportion of patients with ER positivity was higher compared to estrogen and HER2 receptors (51.4, 37.8 and $29.7 \%$, respectively). Ki67 was classified according to a $14 \%$ cutoff value, which has been applied in most clinical practices $(55,56)$. The majority of patients had Ki67 levels of $>14 \%$ (81.1\%), with invasive ductal carcinoma being the tumor type with the higher proliferative index (83.3\%).

Klotho-related parameter analysis. Based on the results of the ELISA, participants were divided into detected and undetected $\alpha$ Klotho groups. A total of 52 patients were undetectable for $\alpha$ Klotho, while only 22 presented varying detectable quantities. In the control group, only 28 individuals had detectable Klotho values. The histopathological categorical variables were presented in relation to the detection of $\alpha$ Klotho (Table III). All analyses demonstrated that the histopathological variables were independent of the detection of $\alpha$ Klotho.

The influence of histopathological features on $\alpha$ Klotho production was then investigated. The data are displayed in Table IV. For this purpose, only patients with detectable $\alpha$ Klotho were considered. Patients that reported comorbidities produced higher levels of $\alpha$ Klotho compared with patients that did not $(249.4 \pm 167.9$ and $71.8 \pm 43.7 \mathrm{pg} / \mathrm{ml} ; \mathrm{P}=0.001)$. The analysis of the Ki67 status, based on a cutoff value of $14 \%$, also demonstrated a possible influence on the concentration of soluble $\alpha$ Klotho $(\mathrm{P}=0.04)$, with the samples presenting Ki67 $>14 \%$ being associated with increased levels of $\alpha$ Klotho $(205.7 \pm 163.3 \mathrm{pg} / \mathrm{ml})$, while those with $\mathrm{Ki} 67<14 \%$ were related to decreased levels of $\alpha$ Klotho $(52.7 \pm 3.1 \mathrm{pg} / \mathrm{ml})$. For all other categorical variables, the production of $\alpha \mathrm{K}$ lotho was not significantly different.

Survival plots. To elucidate whether the production of $\alpha$ Klotho may serve as a predictor of survival of patients with breast cancer, the overall survival was compared among histopathological variables (Fig. 1), followed by a proportion test analysis with Klotho detection among those variables (Table V). Data were collected from the NUPPEC's database for a 60-month period and analyzed through a Cox regression summary (with $95 \%$ confidence interval) and accompanying survival plots were generated.

The detection of Klotho in the serum did not grant any significant advantage to patient survival ( $\mathrm{P}=0.18$; Fig. $1 \mathrm{~A})$, but patients with undetectable levels had a slightly lower survival rate $(63.7 \%)$ when compared to patients with detectable levels (79.7\%) (Fig. 1A).

In addition, the detection of $\alpha$ Klotho was not considered a good prognostic factor by univariate Cox regression [hazard ratio=1.9 (95\% CI: $0.6,5.8), \mathrm{P}=0.223]$. At the end of the observation period, only $37 \%$ of patients with poorly differentiated tumors survived, compared with $79.8 \%$ of patients with moderately differentiated tumors and $100 \%$ of those with well-differentiated tumors $(\mathrm{P}=0.001$; Fig. 1B). Considering only patients with poorly differentiated tumors, $86.4 \%$ did not present with any detectable $\alpha$ Klotho. This number of patients was significantly higher than that of patients with detectable $\alpha$ Klotho (13.6\%) $(\mathrm{P}<0.001 ;$ Table V). 
Table I. Patient characteristics, habits and HRT $(n=134)$.

\begin{tabular}{|c|c|c|c|c|c|c|}
\hline Item & Patients $(n=74)$ & P-value & Controls $(n=60)$ & P-value & Total & P-value \\
\hline Age, years & & 1 & & 0.071 & & 0.227 \\
\hline$\leq 50$ & $37(50.0)$ & & $23(38.3)$ & & $60(44.8)$ & \\
\hline$>50$ & $37(50.0)$ & & $37(61.7)$ & & $74(55.2)$ & \\
\hline Menopausal status & & 0.163 & & $<0.001$ & & $<0.001$ \\
\hline Pre-menopausal & $31(41.9)$ & & $17(28.3)$ & & $48(35.8)$ & \\
\hline Post-menopausal & $43(58.1)$ & & $43(71.7)$ & & $86(64.2)$ & \\
\hline HRT & & $<0.001$ & & & & \\
\hline No & $66(89.2)$ & & & & & \\
\hline Yes & $8(10.8)$ & & & & & \\
\hline $\begin{array}{l}\text { Body weight status according to } \\
\text { body mass index }\end{array}$ & & 0.001 & & 0.002 & & $<0.001$ \\
\hline Underweight & $6(8.1)$ & & $3(5.0)$ & & $9(6.7)$ & \\
\hline Normal range & $18(24.3)$ & & $24(40.0)$ & & $42(31.3)$ & \\
\hline Overweight & $30(40.6)$ & & $17(28.3)$ & & $47(35.1)$ & \\
\hline Obese & $20(27.0)$ & & $16(27.7)$ & & $36(26.9)$ & \\
\hline Alcohol use $\mathrm{a}^{\mathrm{a}}$ & & $<0.001$ & & $<0.001$ & & $<0.001$ \\
\hline Sporadic use & $17(23.0)$ & & $19(32.2)$ & & $36(27.1)$ & \\
\hline Past use & $9(12.2)$ & & $6(10.2)$ & & $15(11.3)$ & \\
\hline Alcoholic & $5(6.8)$ & & $1(1.7)$ & & $6(4.5)$ & \\
\hline Never used & $43(58.0)$ & & $33(55.9)$ & & $76(57.1)$ & \\
\hline Smokinga & & $<0.001$ & & $<0.001$ & & $<0.001$ \\
\hline Never smoked & $45(61.6)$ & & $42(70.0)$ & & $87(65.4)$ & \\
\hline Smoker & $10(13.7)$ & & $5(8.3)$ & & $15(11.3)$ & \\
\hline Former smoker & $18(24.7)$ & & $13(21.7)$ & & $31(23.3)$ & \\
\hline Exposure to second-hand smoke & & 0.005 & & $<0.001$ & & $<0.001$ \\
\hline No & $25(33.8)$ & & $16(26.7)$ & & $41(30.6)$ & \\
\hline Yes & $49(66.2)$ & & $44(73.3)$ & & $93(69.4)$ & \\
\hline Physical activity & & $<0.001$ & & 0.071 & & $<0.001$ \\
\hline No & $65(87.8)$ & & $37(61.7)$ & & $102(76.1)$ & \\
\hline Yes & $9(12.2)$ & & $23(38.3)$ & & $32(23.9)$ & \\
\hline
\end{tabular}

${ }^{a}$ Total patients with data on alcohol use and smoking, $n=133$. Values are expressed as $n(\%)$. The $\chi^{2}$ goodness of fit test was used for patients and controls separately and for both. Data for HRT in controls were not collected. HRT, hormone replacement therapy.

Lymph node status was also demonstrated to significantly affect patient survival $(\mathrm{P}=0.03)$, with positive lymph node status resulting in a patient survival rate of $57.3 \%$ when compared to negative lymph node status, where the survival rate was $79.8 \%$ (Fig. 1C). Of note, among the patients with positive lymph node status, $79.4 \%$ had undetectable $\alpha$ Klotho, vs. $20.6 \%$ with detectable levels $(\mathrm{P}<0.001$; Table V).

The tumor's molecular subtype also influenced patient survival ( $\mathrm{P}=0.0045$; Fig. 1D), while survival curves for patients with luminal and HER2+ tumors were similar after a 60 -month period (78 and $77 \%$, respectively). Patients with a triple-negative subtype, considered to be the most aggressive and difficult to treat type, had the lowest survival rate, with only $\sim 50 \%$ of the patients surviving after 60 months. It is important to note that most of the triple-negative patients did not present with any detectable $\alpha$ Klotho (80\%), which is significantly higher than the percentage of patients with detectable $\alpha$ Klotho (20\%, P=0.003; Table V).

Tumor metastasis staging also influenced patient survival, with metastatic tumors causing lower survival than initial tumors $(\mathrm{P}=0.0011$; Fig. 1E). As with the other variables assessed, most of the patients with metastatic tumors did not have any detectable $\alpha$ Klotho (78.4\%), which differed significantly from patients without metastasis $(21.6 \%, \mathrm{P}<0.001)$. In the present study, the number of patients with and without metastasis was the same $(50 \%)$. When analyzing patients with metastatic tumors, it was indicated that most patients had undetectable $\alpha$ Klotho (78.4\%) and this proportion was significantly higher than that of patients with detectable $\alpha$ Klotho $(21.6 \%, \mathrm{P}<0.001$; Table V).

To estimate the influence on patient survival and to define the hazard of death, a multivariate Cox regression model with explanatory variables, represented in Fig. 1, was applied. The 
Table II. Distribution of histological features of patients with breast cancer $(n=74)$.

\begin{tabular}{|c|c|c|c|c|c|c|}
\hline Histopathological variable & Undetectable & P-value & Detectable & P-value & Total & P-value \\
\hline Histology & & $<0.001$ & & $<0.001$ & & $<0.001$ \\
\hline Ductal carcinoma in situ & $2(3.85)$ & & $1(4.6)$ & & $3(4.1)$ & \\
\hline Invasive ductal carcinoma & $48(92.31)$ & & $18(81.8)$ & & $66(89.1)$ & \\
\hline Invasive lobular carcinoma & $2(3.85)$ & & $3(13.6)$ & & $5(6.8)$ & \\
\hline Tumor grade & & $<0.001$ & & $<0.001$ & & $<0.001$ \\
\hline Well-differentiated & $3(5.8)$ & & $1(4.6)$ & & $4(5.4)$ & \\
\hline Moderately differentiated & $30(57.7)$ & & $18(81.8)$ & & $48(64.9)$ & \\
\hline Poorly differentiated & $19(35.5)$ & & $3(13.6)$ & & $22(29.7)$ & \\
\hline Metastasis stage & & 0.405 & & 0.201 & & 1.000 \\
\hline Initial & $23(44.2)$ & & 14 (63.7) & & $37(50.0)$ & \\
\hline Metastatic & $29(55.8)$ & & $8(36.4)$ & & $37(50.0)$ & \\
\hline TNM classification & & $\mathrm{NC}$ & & $\mathrm{NC}$ & & $\mathrm{NC}$ \\
\hline I & $6(11.5)$ & & $3(13.6)$ & & $9(12.2)$ & \\
\hline II & $17(32.7)$ & & $11(50.0)$ & & $28(37.8)$ & \\
\hline III & $22(42.3)$ & & $3(13.6)$ & & $25(33.8)$ & \\
\hline IV & $7(13.5)$ & & $5(22.7)$ & & $12(16.2)$ & \\
\hline Tumor size, $\mathrm{cm}$ & & 0.189 & & $\mathrm{NC}$ & & $\mathrm{NC}$ \\
\hline$<2$ & $7(13.5)$ & & $4(18.2)$ & & $11(14.9)$ & \\
\hline $2-5$ & $18(34.6)$ & & $10(45.5)$ & & $28(37.8)$ & \\
\hline$>5$ & $13(25.0)$ & & $5(22.7)$ & & $18(24.3)$ & \\
\hline Invasive & $14(26.9)$ & & $3(13.6)$ & & $17(23.0)$ & \\
\hline Lymph node status & & 0.166 & & 0.201 & & 0.642 \\
\hline Negative & $21(40.4)$ & & $14(63.6)$ & & $35(47.3)$ & \\
\hline Positive & $31(59.6)$ & & $8(36.4)$ & & $39(52.7)$ & \\
\hline Molecular subtype & & 0.092 & & 0.009 & & 0.005 \\
\hline Triple-negative & $20(38.5)$ & & $5(22.7)$ & & $25(33.8)$ & \\
\hline Luminal & $22(42.3)$ & & $14(63.6)$ & & $36(48.6)$ & \\
\hline HER2+ & $10(19.2)$ & & $3(13.6)$ & & $13(17.6)$ & \\
\hline Progesterone receptor & & 0.096 & & 0.201 & & 0.036 \\
\hline Negative & $32(61.5)$ & & $14(63.6)$ & & $46(62.2)$ & \\
\hline Positive & $20(38.5)$ & & $8(36.4)$ & & $28(37.8)$ & \\
\hline Estrogen receptor & & 0.579 & & 0.201 & & 0.816 \\
\hline Negative & $28(53.8)$ & & $8(36.4)$ & & $36(48.6)$ & \\
\hline Positive & $24(46.2)$ & & $14(63.6)$ & & $38(51.4)$ & \\
\hline HER 2 protein & & $<0.001$ & & 0.394 & & $<0.001$ \\
\hline Negative & $39(75.0)$ & & $13(59.1)$ & & $52(70.3)$ & \\
\hline Positive & $13(25.0)$ & & $9(40.9)$ & & $22(29.7)$ & \\
\hline $\mathrm{Ki} 67, \%$ & & $<0.001$ & & $<0.001$ & & $<0.001$ \\
\hline$<14$ & $11(21.2)$ & & $3(13.6)$ & & $14(18.9)$ & \\
\hline$\geq 14$ & $41(78.8)$ & & $19(86.4)$ & & $60(81.1)$ & \\
\hline
\end{tabular}

Values are expressed as $\mathrm{n}(\%)$. The P-value was not calculated by the $\chi^{2}$ goodness-of-fit test as the assumption of at least 5 expected frequencies in each group of the categorical variable was violated. NC, not calculated; HER2, human epidermal growth factor receptor 2.

analysis indicated that the variables of molecular subtype and the presence of metastasis were important prognostic factors for the patients analyzed (Table VI).

Activation of ER enhances the expression of the Klotho gene and soluble $\alpha$ Klotho. Due to triple-negative tumors displaying undetectable quantities of Klotho, an assay to evaluate the ER's influence on soluble Klotho and gene expression was performed. The MCF-7 cell line was treated with the ER agonist E2, or with DPN, the ER $\beta$-specific agonist. DPN increased the levels of soluble $\alpha$ Klotho in the MCF-7 supernatant. E2 and DPN induced mRNA expression of $\alpha$ Klotho, and of note, 
Table III. Histopathological variables by detectability of Klotho $(n=74)$.

\begin{tabular}{|c|c|c|c|}
\hline \multirow[b]{2}{*}{ Histopathological variable } & \multicolumn{2}{|c|}{ Klotho detection } & \multirow[b]{2}{*}{ Statistical description } \\
\hline & Undetectable $(\mathrm{n}=52)$ & Detectable $(n=22)$ & \\
\hline Histology & & & ${ }^{\mathrm{a}} \mathrm{P}=0.313$ \\
\hline Ductal carcinoma in situ & $2(2.7)$ & $1(1.4)$ & \\
\hline Invasive ductal carcinoma & $48(64.9)$ & $18(24.3)$ & \\
\hline Invasive lobular carcinoma & $2(2.7)$ & $3(4.1)$ & \\
\hline Tumor grade & & & ${ }^{\mathrm{a}} \mathrm{P}=0.091$ \\
\hline Well-differentiated & $3(4.1)$ & $1(1.4)$ & \\
\hline Moderately differentiated & $30(40.5)$ & $18(24.3)$ & \\
\hline Poorly differentiated & $19(25.7)$ & $3(4.1)$ & \\
\hline Metastasis stage & & & $\chi^{2}(1)=2.33, P=0.127$ \\
\hline Initial & $23(31.1)$ & $14(18.9)$ & \\
\hline Metastatic & $29(39.2)$ & $8(10.9)$ & \\
\hline TNM classification & & & ${ }^{\mathrm{a}} \mathrm{P}=0.099$ \\
\hline I & $6(8.1)$ & $3(4.1)$ & \\
\hline II & $17(23.0)$ & $11(14.9)$ & \\
\hline III & $22(29.7)$ & $3(4.1)$ & \\
\hline IV & $7(9.5)$ & $5(6.8)$ & \\
\hline Tumor size, cm & & & ${ }^{\mathrm{a}} \mathrm{P}=0.604$ \\
\hline$<2$ & $7(9.5)$ & $4(5.4)$ & \\
\hline $2-5$ & $18(24.3)$ & $10(13.5)$ & \\
\hline$>5$ & $13(17.6)$ & $5(6.8)$ & \\
\hline Invasive & $14(18.9)$ & $3(4.1)$ & \\
\hline Lymph node status & & & $\chi^{2}(1)=3.35, P=0.067$ \\
\hline Negative & $21(28.4)$ & $14(18.9)$ & \\
\hline Positive & $31(41.9)$ & $8(10.8)$ & \\
\hline Molecular subtype & & & ${ }^{\mathrm{a} P}=0.269$ \\
\hline Triple-negative & $20(27.0)$ & $5(6.8)$ & \\
\hline Luminal & $22(29.7)$ & $14(18.9)$ & \\
\hline HER2+ & $10(13.5)$ & $3(4.1)$ & \\
\hline Progesterone receptor & & & ${ }^{\mathrm{a}} \mathrm{P}=1.000$ \\
\hline Negative & $32(43.2)$ & $14(18.9)$ & \\
\hline Positive & $20(27.0)$ & $8(10.8)$ & \\
\hline Estrogen receptor & & & ${ }^{\mathrm{a}} \mathrm{P}=0.208$ \\
\hline Negative & $28(37.8)$ & $8(10.8)$ & \\
\hline Positive & $24(32.4)$ & $14(18.9)$ & \\
\hline HER2 & & & ${ }^{\mathrm{a}} \mathrm{P}=0.265$ \\
\hline Negative & $39(52.7)$ & $13(17.6)$ & \\
\hline Positive & $13(17.6)$ & $9(12.2)$ & \\
\hline Ki67,\% & & & ${ }^{\mathrm{a}} \mathrm{P}=0.534$ \\
\hline$<14$ & $11(14.9)$ & $3(4.1)$ & \\
\hline$>14$ & $41(55.4)$ & $19(25.7)$ & \\
\hline
\end{tabular}

Values are expressed as $\mathrm{n}(\%) .{ }^{\mathrm{a}}$ Fisher's exact test for the variables with the expected count $<20 \%$. HER2, human epidermal growth factor receptor 2 .

the specific activation of ER $\beta$ tripled the gene expression of $\alpha$ Klotho $(\mathrm{P}<0.01$; Fig. 2). In addition, proliferation was analyzed by CFSE. In contrast to DPN treatment, E2 treatment stimulated the proliferation of MCF-7 cells (data not shown).

\section{Discussion}

Due to the prevalence and severity of breast cancer, the identification of diagnostic and prognostic biomarkers is 
Table IV. Klotho detectable levels and relation with histopathological features $(n=22)$.

\begin{tabular}{|c|c|c|c|}
\hline Item & $\mathrm{N}$ & Klotho levels, pg/ml & Statistical description \\
\hline Group & & & $\mathrm{U}=292, \mathrm{P}=0.754$ \\
\hline Patients & 22 & $185.0 \pm 160.0$ & \\
\hline Controls & 28 & $188.0 \pm 180.0$ & \\
\hline Metastasis stage & & & $\mathrm{H}(1)=0.787, \mathrm{P}=0.375$ \\
\hline Initial & 14 & $223.2 \pm 188.4$ & \\
\hline Metastatic & 8 & $118.0 \pm 56.6$ & \\
\hline TNM classification & & & $\mathrm{H}(3)=1.69, \mathrm{P}=0.639$ \\
\hline I & 3 & $224.0 \pm 220.5$ & \\
\hline II & 11 & $223.0 \pm 190.8$ & \\
\hline III & 3 & $150.7 \pm 60.9$ & \\
\hline IV & 5 & $97.8 \pm 49.4$ & \\
\hline Molecular subtype & & & $\mathrm{H}(2)=2.74, \mathrm{P}=0.254$ \\
\hline Triple-negative & 5 & $97.8 \pm 77.6$ & \\
\hline Luminal & 14 & $226.1 \pm 184.0$ & \\
\hline HER2+ & 3 & $137.0 \pm 62.1$ & \\
\hline Tumor size, $\mathrm{cm}$ & & & $\mathrm{H}(3)=3.22, \mathrm{P}=0.358$ \\
\hline$<2$ & 4 & $273.0 \pm 205.2$ & \\
\hline $2-5$ & 10 & $151.0 \pm 172.3$ & \\
\hline$>5$ & 5 & $231.0 \pm 129.1$ & \\
\hline Invasive & 3 & $101.0 \pm 56.6$ & \\
\hline Lymph node status & & & $\mathrm{U}=43, \mathrm{P}=0.402$ \\
\hline Negative & 14 & $223.0 \pm 188.4$ & \\
\hline Positive & 8 & $118.0 \pm 56.6$ & \\
\hline Progesterone receptor & & & $\mathrm{U}=43, \mathrm{P}=0.402$ \\
\hline Negative & 14 & $157.0 \pm 136.0$ & \\
\hline Positive & 8 & $234.0 \pm 197.0$ & \\
\hline Estrogen receptor & & & $\mathrm{U}=35, \mathrm{P}=0.165$ \\
\hline Negative & 8 & $113.0 \pm 70.4$ & \\
\hline Positive & 14 & $226.0 \pm 184.0$ & \\
\hline HER2 receptor & & & $\mathrm{U}=40, \mathrm{P}=0.235$ \\
\hline Negative & 13 & $150.0 \pm 135.0$ & \\
\hline Positive & 9 & $235.0 \pm 189.0$ & \\
\hline Ki67,\% & & & $\mathrm{U}=6, \mathrm{P}=0.03$ \\
\hline$<14$ & 3 & $52.7 \pm 3.1$ & \\
\hline$\geq 14$ & 19 & $205.7 \pm 163.3$ & \\
\hline
\end{tabular}

Values are expressed as the mean \pm standard deviation. Histology variables were not included due to ductal in situ having only 1 patient with detectable Klotho. HER2, human epidermal growth factor receptor 2.

essential (57). There are several biomarkers (i.e., EGFR, HER2, PgR, ER) that require analysis, but in certain cases, it is not possible to collect histological samples. Therefore, it is important to identify serum biomarkers that make the prognosis or diagnosis more reliable.

Proteins secreted from the tumors and detected in patients' fluids may be collected and analyzed and are thus used as clinical markers for breast tumor prognosis and diagnosis. The plasma concentration of Klotho protein may be regarded as a potential biomarker, since it inhibits signaling pathways, contributing to carcinogenesis $(58,59)$. Furthermore, certain studies have demonstrated that cases of cancer with the least favorable prognosis, such as advanced cases, exhibit dysregulations in the Klotho gene, including epigenetic silencing $(24,29)$. Certain in vitro studies have demonstrated that human tumor-derived cell lines do not express Klotho as normal cell lines do $(23,34,60,61)$. The most consolidated data of antitumor action is that soluble Klotho inhibits the IGF-1 signaling pathway by blocking the auto-phosphorylation of the IGF-1 receptor and also inhibits Wnt- $\beta$-catenin, MAPK, PIK3A, AKT, unfolded protein response, stanniocalcin-1 and TGF- $\beta 1$ pathways $(26,60,62)$. 
Table V. Overall survival compared between groups with undetectable and detectable $\alpha$ Klotho.

\begin{tabular}{|c|c|c|c|}
\hline Histopathological variables & Undetectable & Detectable & P-value \\
\hline \multicolumn{4}{|l|}{ Molecular subtype } \\
\hline Luminal & $22(61.1)$ & $14(38.9)$ & 0.182 \\
\hline Triple-negative & $20(80.0)$ & $5(20.0)$ & 0.003 \\
\hline \multicolumn{4}{|l|}{ Lymph node status } \\
\hline Positive & $31(79.5)$ & $8(20.5)$ & $<0.001$ \\
\hline Negative & $21(60.0)$ & $14(40.0)$ & 0.237 \\
\hline \multicolumn{4}{|l|}{ Metastasis stage } \\
\hline Initial & $23(62.2)$ & $14(37.8)$ & 0.139 \\
\hline Metastatic & $29(78.4)$ & $8(21.6)$ & $<0.001$ \\
\hline \multicolumn{4}{|l|}{ Tumor grade } \\
\hline Well-differentiated & $3(75.0)$ & $1(25.0)$ & 0.317 \\
\hline Moderately differentiated & $30(62.5)$ & $18(37.5)$ & 0.083 \\
\hline Poorly differentiated & $19(86.4)$ & $3(13.6)$ & $<0.001$ \\
\hline
\end{tabular}

A

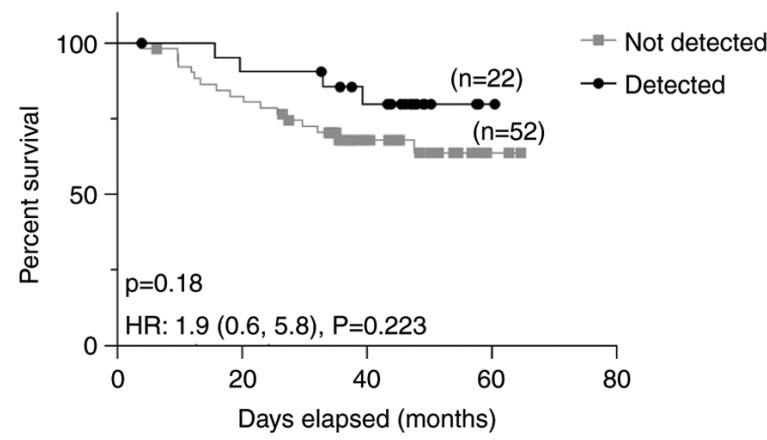

C

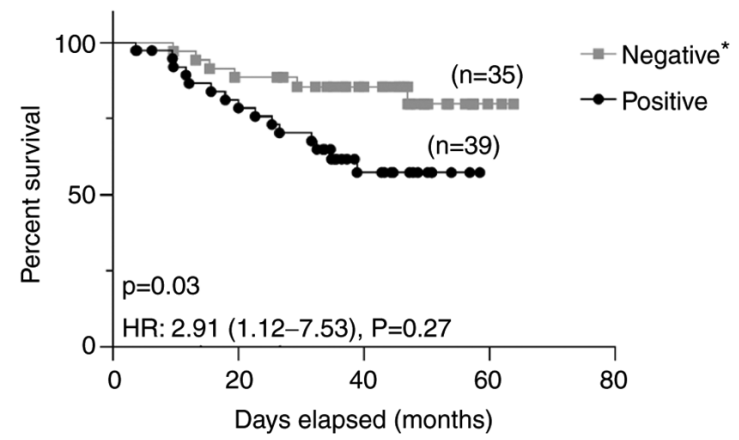

B

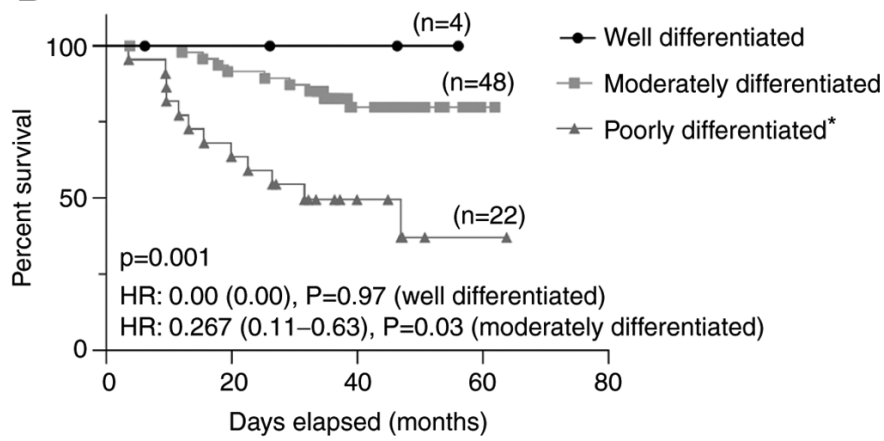

D

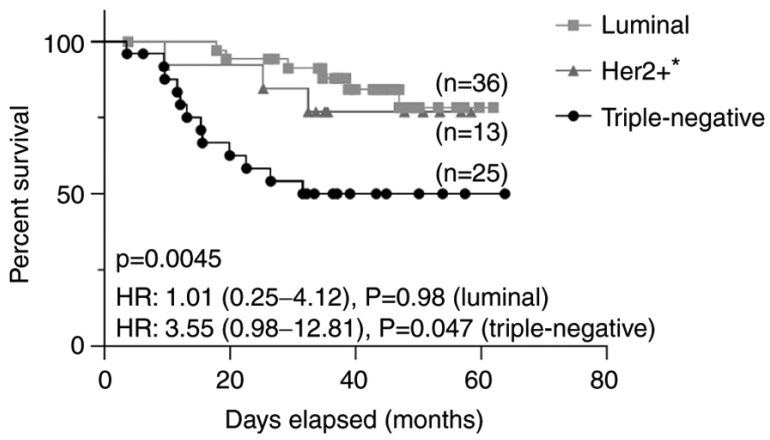

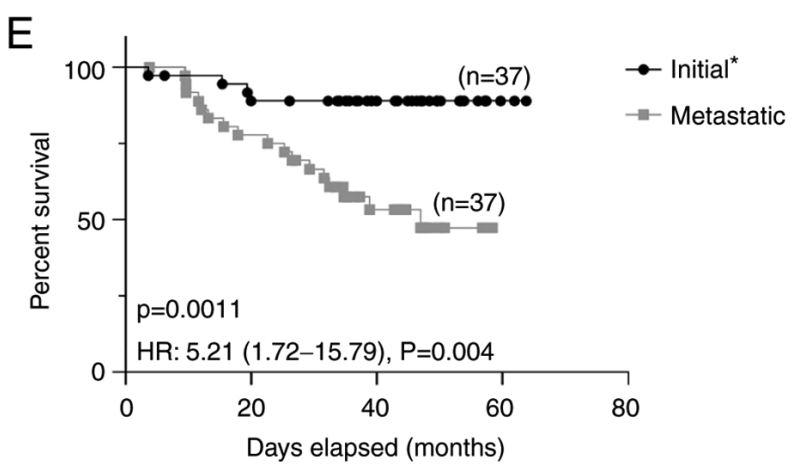

Figure 1. Progression-free survival curves according to the level of soluble $\alpha$ Klotho and tumor variables. (A) Relation between $\alpha$ Klotho levels and survival, (B) degree of differentiation, (C) lymph node status, (D) the tumor's molecular subtype and (E) metastasis staging. Log-rank tests were used to compare groups. The logistic regression using the Cox linear hazards model was used to evaluate the probability of death amongst groups. *Reference category. HR, hazard ratio; HER2, human epidermal growth factor receptor 2. 
Table VI. Multivariate analysis for histopathological variables associated with poor survival.

Multivariate analysis ${ }^{\mathrm{a}}$

Variable

LogRank (Mantel-Cox) P-value

HR $(95 \%$ CI $) \quad$ P-value

Molecular subtype

0.0045

Triple-negative

$3.55(0.98-12.81)$

0.047

Luminal

$1.01(0.25-4.12)$

0.98

HER2+

REF

Lymph node involvement

0.0296

$2.91(1.12-7.53)$

0.27

Metastasis stage (metastatic vs. initial)

0.0011

$5.21(1.72-15.79)$

0.004

Tumor grade

0.001

Well-differentiated

$0.00(0.00)$

0.97

Moderately differentiated

$0.267(0.11-0.63)$

0.03

Poorly differentiated

REF

${ }^{a}$ Variables included in multivariate regression Cox model. HER2, human epidermal growth factor receptor 2; HR, hazard ratio; REF, reference category.

A

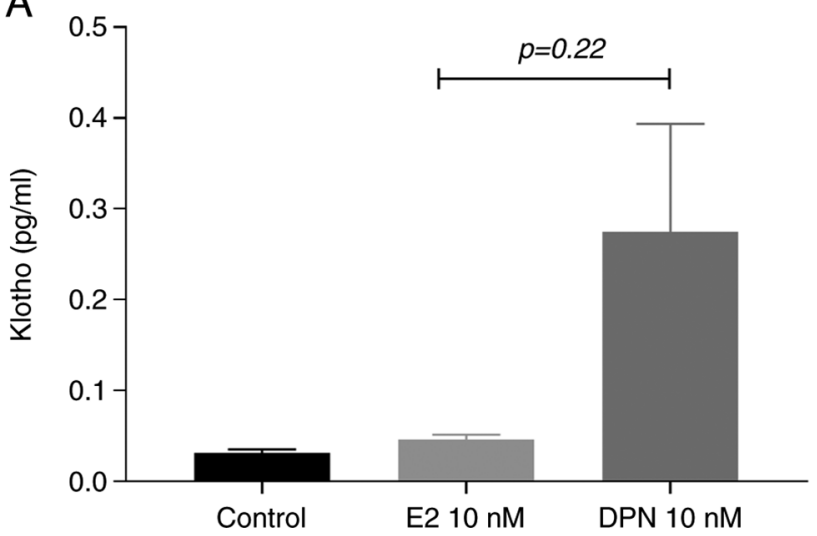

B

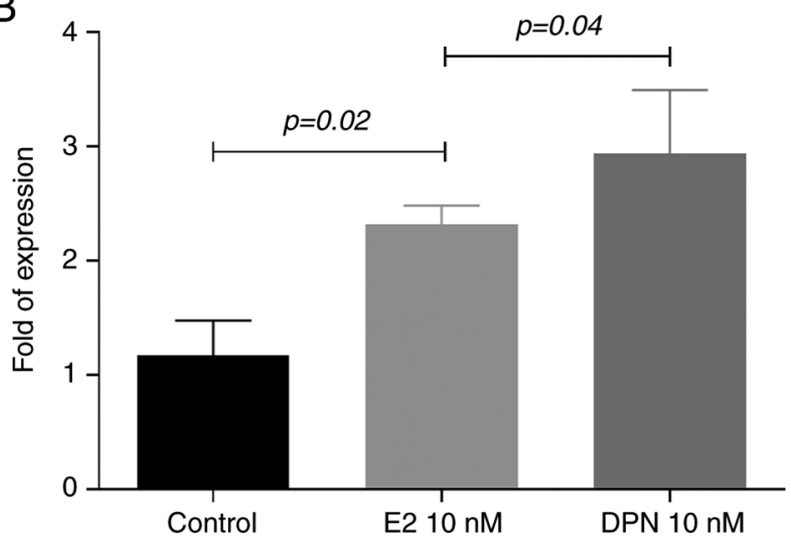

Figure 2. Soluble $\alpha$ Klotho and mRNA expression after the use of ER agonists in the luminal line of breast cancer. MCF-7 was incubated with E2 and DPN, an ER $\beta$-specific agonist, for $48 \mathrm{~h}$. (A) MCF-7 produced more $\alpha$ Klotho if incubated with DPN. Results with significant differences were determined using Welch's ANOVA $[F(2,2.5)=8.30, P=0.076$. Post-test: Tukey]. (B) Both E2 and DPN induced gene expression of Klotho in MCF-7 cells. Values are expressed as the mean \pm standard error of the mean, derived from three biological replicates, each containing a technical triplicate. Significant differences were determined using one-way ANOVA [F (2.6)=16.75, P=0.003. Post-test: Tamhane's T2]. DPN, diarylpropionitrile; E2, non-specific ER agonist estradiol; ER, estrogen receptor.

As previously mentioned, in a cancer situation, the production of $\alpha$ Klotho must be lower in patients compared with controls. The data obtained in the present study proved that the concentration of $\alpha$ Klotho was not different between breast cancer patients and controls. These results are in agreement with those of a study on patients with lung cancer, which exhibited no differences in Klotho concentrations when compared to controls (63). In the present study, the control group was composed of patients' relatives, which may be a potential limitation for the detection of Klotho, as the family history of breast cancer may have had an influence. However, another study involving invasive ductal breast carcinoma suggested that, while the number of patients and controls with high levels of $\alpha$ Klotho was similar, there was a higher number of patients with cancer with low levels or absence of $\alpha$ Klotho (25). Based on the reduced expression of the Klotho gene reported in a previous publication (25), lower detection of $\alpha$ Klotho was expected in patients with breast cancer. The reason for the cancer-associated decrease of $\alpha$ Klotho remains elusive and the present study did not investigate any histological samples, and it remains undetermined whether the $\alpha$ Klotho present in the serum represents the levels of Klotho in the tumor.

The protective effect of Klotho has been observed in various diseases, including cancers $(17,41,59,64)$. The participants of the present study were classified according to the detection of $\alpha$ Klotho based on the optical density in the ELISA assay. Measurements below the lowest point in the standard curve obtained by ELISA were defined as undetected and the others were considered detected. Most of the patients with positive lymph node status were classified as having undetected $\alpha$ Klotho. These results raise the question of whether there is a possible link between metastasis to lymph nodes and Klotho. Tumors, in favor of their survivability, work towards inhibiting factors that lower their proliferation 
and spread. Epigenetic silencing of Klotho promotes cancer progression due to the reduction of circulating soluble Klotho (29), which, in turn, facilitates events that facilitate metastasis, such as epithelial-mesenchymal transition (35). In a study investigating large cell neuroendocrine carcinoma of the lung, Klotho expression was indicated to augment the survival of patients with lymph-node involvement when compared to those without such involvement (30). However, in large cell lung carcinoma, lymph-node involvement and Klotho were indicated to be independent factors predictive of tumor progression (65). While Klotho exhibits potential in the prevention of metastasis, its role in specific cancers still requires further investigation. Most likely, the reduction or absence of Klotho in the tumor microenvironment increases the population of undifferentiated cells, favoring their local detachment and metastasis $(29,35)$.

The Ki67 index is one of the most important prognostic markers used in clinical oncology for patients with breast cancer, which, in the present study, was measured by immunohistochemistry (66-68). Circulating Ki67 may be used as a biomarker in acute lymphoblastic leukemia (69), but in breast cancer, it appears to not be as reliable as immunohistochemistry (55), since soluble biomarkers may not directly represent what occurs in the tumor. The 2011 Saint Gallen Consensus Meeting defined 'low proliferation' tumors as those with a Ki67 index of $<14 \%$ (70). Likewise, during this same meeting in 2013, a consensus was reached according to which a Ki67 index of $>20 \%$ was considered a 'high' Ki67 status. At the same time, numerous studies on different types of tumor indicated that $\mathrm{Ki} 67$ expression is associated with intermediate proliferation activities (between 15 and 30\%) (69-75). In the present study, a cutoff of $14 \%$ was employed due to its routine use at the Oncology Center of the Federal University of Uberlandia (Uberlandia, Brazil). $\alpha$ Klotho was not detected in most patients with $\mathrm{Ki} 67<14 \%$, in contrast to patients with $\mathrm{Ki} 67$ $>14 \%$. As a marker of proliferation and negative prognosis, $\mathrm{Ki} 67$ is frequently associated with lower Klotho concentrations (25). In this sense, the reflection of Klotho in the Ki67 index may be based on the inhibition of IGF-1, a pathway that has a direct relation to cell proliferation, differentiation and survival (through the negation of apoptosis) $(25,76)$. Therefore, these unexpected results are probably due to systemic $\alpha$ Klotho possibly not representing the local production of Klotho. Other publications have already demonstrated that biomarkers such as carcinoembryonic antigen, ER $\beta$, cytokeratin 19 and c-Myc present in serum do not represent the production in a tumor microenvironment (77).

Klotho is a protein that is considered to be closely tied to lifespan; therefore, investigating the overall lifespan of patients was of interest. There was no difference in overall patient survival depending on $\alpha$ Klotho status, but results similar to those encountered in the literature were obtained when considering certain variables, such as molecular subtype, tumor grade, lymph node status and TNM classification (78-81). The present results demonstrated that patients with tumors that had certain histopathological variables considered important for overall survival had undetected $\alpha$ Klotho. The relationship between Klotho and cancer patient survival was also investigated in other studies. For instance, in a study on patients with ovarian cancer, the expression of Klotho in tissue was decreased compared with that in the control group and reduced Klotho was associated with decreased survival rates (31). In small-cell lung cancer, Klotho expression in tissue samples was significantly associated with overall survival (82). The present results and the reports in the literature demonstrated that Klotho has potential use in oncological therapy, specifically in helping to enhance treatment and improve patient survival. The relationship between Klotho and oncological treatment has also been investigated in small-cell lung cancer, where the administration of perioperative chemotherapy in patients with undetectable Klotho had no significant effect in terms of improving survival, while patients with detectable Klotho benefited from perioperative chemotherapy. In addition, patients with undetectable Klotho had much lower overall survival in a previous study (82).

Although the $\alpha$ Klotho status did not directly influence the survival curve, when analyzing variables with lower overall survival, such as metastatic tumors, tumors with poor differentiation, positive lymph status and triple-negative tumors, the number of patients with undetectable $\alpha$ Klotho was predominant. Despite this, a significant disadvantage of the present study was the lack of establishment of causal effects between the detectability of $\alpha$ Klotho and the histopathological variables, besides that this association may be explained by other variables that differ from the detection of $\alpha$ Klotho. Thus, it was demonstrated that most of the patients with undifferentiated triple-negative metastatic tumors did not produce detectable levels of $\alpha$ Klotho.

The present results indicated that there were more patients with undetectable Klotho and lymph-node involvement compared to patients with detectable Klotho, which may indicate that the absence of Klotho results in poor prognosis and may contribute to the spread of the tumor to lymph nodes. The association of metastasis with lymph nodes is frequently observed in studies that deal with breast cancer $(83,84)$. Studies have demonstrated the importance of Klotho in inhibiting metastasis in mice $(26,85)$. Due to the results of previous studies, Klotho was expected to have an important function in protecting patients against tumor progression. This safeguard of Klotho goes beyond just acting against metastasis, but it also has a role in reducing proliferation in various types of cancer, such as breast and hepatocellular cancer, lymphomas and pancreatic cancers $(23,25,28,49,86)$. While results point to a relationship between these factors, the association between Klotho and lymph-node involvement remains poorly understood and requires further investigation. Attempts to unveil the relationship between these factors have provided controversial results. For instance, one study of large-cell neuroendocrine lung carcinoma revealed that lymph-node involvement and Klotho expression are independent factors influencing patient survival (65), whereas another study on the same type of cell concluded that despite being independent factors, among patients without lymph-node involvement, metastasis or angioinvasion, the effects of Klotho in ensuring survival of patients were significantly greater (30).

In the advanced stages of metastasis, it is common for tumor cells to exhibit accelerated cellular proliferation (87). As one of the consequences of this accelerated cellular proliferation, cancer cells tend to present with a lower degree of differentiation (88). The majority of subjects in the present 
study had moderately or poorly differentiated tumors, with most of these same subjects also having undetectable levels of Klotho. According to the literature, the role of Klotho may be indirect, through binding to growth factors, such as FGF-23, to assist in cellular differentiation of several cell types, such as neural cells (89), adipose-derived stem cells (90), muscle stem cells (91) and bone cells (92). Therefore, the absence of Klotho in the subjects of the present study may have contributed to the lack of differentiation.

Triple-negative breast cancer, a tumor subtype devoid of hormone receptors and HER2, is associated with significantly lower overall survival, along with those with negative ER/PgR, and of these patients, a larger proportion had undetectable levels of Klotho. In agreement with the present results, another study suggested that in patients with triple-negative breast cancer, the levels of $\alpha$ Klotho and $\beta$ Klotho were significantly downregulated, while $\gamma$ Klotho was highly expressed, which correlates with lower disease progression (50). The relationship between Klotho and hormone receptors remains to be elucidated. One study indicated that in the hippocampus of rats during menopause, $17 \beta$-estradiol increased Klotho expression, since Klotho is a target of E2, indicating positive feedback between these compounds (93). In epithelial ovarian cancer, $\alpha$ Klotho may downregulate ER signaling, as $\alpha$ Klotho inhibits the IGF-1 pathway, which in turn regulates the transcriptional activity of ER (94). In MCF-7 cells, proliferation is decreased by Klotho overexpression but enhanced by its downregulation (25). However, Klotho does not appear to affect HER2 $(25,95)$. In vitro assessments of a multitude of different cell lines with and without these receptors demonstrated that Klotho still decreases the proliferation of certain cell types, including 293 cells, yet in other cells, the EGF pathway is not modulated by Klotho, such as in L6 or H4IIE cells (1). The absence of these receptors in patients with triple-negative breast cancer may explain the lack of detectable levels of Klotho, since there is evidence to support the hypothesis that these receptors and Klotho exert a mutual influence.

Due to this context, an investigation of the relationship between ER activity and Klotho expression and $\alpha$ Klotho production was performed. For this purpose, a luminal phenotype breast cancer cell line, MCF-7, was cultured. Based on the different roles of $\mathrm{ER} \alpha$ and $\mathrm{ER} \beta$, cells were incubated with different types of estrogen, one of which has a higher affinity for $E R \alpha$, while the other, DPN, is a highly potent $\operatorname{ER} \beta$ agonist. It was observed that estrogen was able to increase both Klotho gene expression and proliferation of MCF-7 cells, while DPN only stimulated gene expression, without any consequential increase in proliferation (data not shown). In addition, the present results proved that DPN increased Klotho production. Due to these results, ER $\beta$ may be a more reasonable target in oncological therapy if the focus were to increase Klotho concentrations. As an example, genistein, an ER $\beta$ ligand (96), restores Klotho gene expression by inhibiting histone 3 deacetylation of the Klotho promoter and normalizes the promoter DNA hypermethylation by suppressing DNA methyltransferase in renal fibrosis (97). The biological interaction between Klotho and ERs appears to depend on aromatase, an enzyme involved in estrogen production. A study investigating the impact of the absence of aromatase on renal calcium reabsorption (98) suggested that mice with a deficiency of this enzyme had increased Klotho expression, whereas after treatment with the exogenous estrogen, this expression decreased. On the other hand, rats treated with different doses of estrogen increased the levels of Klotho mRNA in a dose-dependent manner in samples of the parathyroid gland (99). This discrepancy may be explained by the different expressions of $\alpha$ - and $\beta$-ERs in different cell lines.

In conclusion, the present results demonstrated that undetectable $\alpha$ Klotho in the serum of patients with breast cancer is related to the most aggressive histopathological characteristics of such tumors and is associated with poor prognosis. Despite the present data demonstrating this relationship, soluble $\alpha$ Klotho may not be representative of the tumor microenvironment and may thus not be a suitable biomarker for breast cancer diagnosis. Thus, the relationship between soluble $\alpha$ Klotho and Klotho present in cancer tissue requires further investigation.

\section{Acknowledgements}

Not applicable.

\section{Funding}

This study was supported by Fundação de Amparo à Pesquisa do Estado de Minas Gerais, Conselho Nacional de Desenvolvimento Científico e Tecnológico, Coordenação de Aperfeiçoamento de Pessoal de Nível Superior by granting scholarships, Programa Nacional de Apoio à Atenção Oncológica (Pronon) (grant no. APQ-00586-14) in partnership with Núcleo de Prevenção, Pesquisa e Projeto de Câncer, Grupo Luta Pela Vida and Hospital do Câncer de Uberlândia.

\section{Availability of data and materials}

The datasets used and/or analyzed during the current study are available from the corresponding author and on reasonable request.

\section{Authors' contributions}

PAA, BCB, LRS, VLCS, FCS, FACL, RAA and MJBS made substantial contributions to conception and design, acquisition of data, or analysis and interpretation of data. BCB, LRS, VLCS, RAA and MJBS drafted the manuscript or revised it critically for important intellectual content. LRS and MJBS checked and approved the authenticity of the raw data. All authors gave their final approval of the version to be published.

\section{Ethics approval and consent to participate}

This project was approved by the Plataforma Brasil Research Ethics Committee under technical advice number 38930314.5.0000.5565. A Term of Consent was signed by each of the participants allowing the use of their information in secondary studies and publications.

\section{Patient consent for publication}

Not applicable. 


\section{Competing interests}

The authors declare that they have no competing interests.

\section{References}

1. Kurosu H, Yamamoto M, Clark JD, Pastor JV, Nandi A, Gurnani P, McGuinness OP, Chikuda H, Yamaguchi M, Kawaguchi $\mathrm{H}$, et al: Suppression of aging in mice by the hormone Klotho. Science 309: 1829-1833, 2005.

2. Kuro-o M, Matsumara Y, Aizawa H, Kawaguchi H, Suga T, Utsugi T, Ohyama Y, Kurabayashi M, Kaname T, Kume E, et al: Mutation of the mouse Klotho gene leads to a syndrome resembling ageing. Nature 390: 45-51, 1997.

3. Nabeshima YI: Klotho: A fundamental regulator of aging. Ageing Res Rev 1: 627-638, 2002.

4. Sopjani M and Dërmaku-Sopjani M: Klotho-dependent cellular transport regulation. Vitam Horm 101: 59-84, 2016.

5. Kharitonenkov A: FGFs and metabolism. Curr Opin Pharmacol 9: 805-810, 2009.

6. Urakawa I, Yamazaki Y, Shimada T, Iijima K, Hasegawa H, Okawa K, Fujita T, Fukumoto S and Yamashita T: Klotho converts canonical FGF receptor into a specific receptor for FGF23. Nature 444: 770-774, 2006.

7. Kurosu H, Ogawa Y, Miyoshi M, Yamamoto M, Nandi A, Rosenblatt KP, Baum MG, Schiavi S, Hu MC, Moe OW and Kuro-o M: Regulation of fibroblast growth factor-23 signaling by Klotho. J Biol Chem 281: 6120-6123, 2006.

8. Ito S, Kinoshita S, Shiraishi N, Nakagawa S, Sekine S, Fujimori T and Nabeshima YI: Molecular cloning and expression analyses of mouse betaklotho, which encodes a novel Klotho family protein. Mech Dev 98: 115-119, 2000

9. Ito S, Fujimori T, Hayashizaki Y and Nabeshima Y: Identification of a novel mouse membrane-bound family 1 glycosidase-like protein, which carries an atypical active site structure. Biochim Biophys Acta 1576: 341-345, 2002.

10. Kim JH, Hwang KH, Park KS, Kong ID and Cha SK: Biological role of anti-aging protein Klotho. J Lifestyle Med 5: 1-6, 2015.

11. Chen CD, Tung TV, Liang J, Zeldich E, Tucker Zhou TB, Turk BE and Abraham CR: Identification of cleavage sites leading to the shed form of the anti-aging protein Klotho. Biochemistry 53 5579-5587, 2014

12. Chen CD, Podvin S, Gillespie E, Leeman SE and Abraham CR: Insulin stimulates the cleavage and release of the extracellular domain of Klotho by ADAM10 and ADAM17. Proc Natl Acad Sci USA 104: 19796-19801, 2007.

13. Bloch L, Sineshchekova O, Reichenbach D, Reiss K, Saftig P, Kuro-o M and Kaether C: Klotho is a substrate for alpha-, betaand gamma-secretase. FEBS Lett 583: 3221-3224, 2009.

14. Akimoto T, Yoshizawa H, Watanabe Y, Numata A, Yamazaki T, Takeshima E, Iwazu K, Komada T, Otani N, Morishita Y, et al: Characteristics of urinary and serum soluble Klotho protein in patients with different degrees of chronic kidney disease. BMC Nephrol 13: 155, 2012.

15. Matsumura Y, Aizawa H, Shiraki-lida T, Nagai R, Kuro-o M and Nabeshima Y: Identification of the human Klotho gene and its two transcripts encoding membrane and secreted Klotho protein. Biochem Biophys Res Commun 242: 626-630, 1998.

16. Imura A, Tsuji Y, Murata M, Maeda R, Kubota K, Iwano A, Obuse C, Togashi K, Tominaga M, Kita N, et al: Alpha-klotho as a regulator of calcium homeostasis. Science 316: 1615-1618, 2007.

17. Xuan NT and Hai N: Changes in expression of Klotho affect physiological processes, diseases, and cancer. Iran J Basic Med Sci 21: 3-8, 2018.

18. Zhou X and Wang X: Klotho: A novel biomarker for cancer. J Cancer Res Clin Oncol 141: 961-969, 2015.

19. Perri F, Longo F, Giuliano M, Sabbatino F, Favia G, Ionna F, Addeo R, Della Vittoria Scarpati G, Di Lorenzo G and Pisconti S: Epigenetic control of gene expression: Potential implications for cancer treatment. Crit Rev Oncol Hematol 111: 166-172, 2017.

20. Chen B, Ma X, Liu S, Zhao W and Wu J: Inhibition of lung cancer cells growth, motility and induction of apoptosis by Klotho, a novel secreted Wnt antagonist, in a dose-dependent manner. Cancer Biol Ther 13: 1221-1228, 2012.

21. Chen TJ, Ren H, Thakur A, Yang T, Li Y, Zhang S, Wang T and Chen M: Decreased level of Klotho contributes to drug resistance in lung cancer cells: Involving in Klotho-mediated cell autophagy. DNA Cell Biol 35: 751-757, 2016.
22. Wang Y, Chen L, Huang G, He D, He J, Xu W, Zou C, Zong F $\mathrm{Li} \mathrm{Y}$, Chen B, et al: Klotho sensitizes human lung cancer cell line to cisplatin via PI3k/Akt pathway. PLoS One 8: e57391, 2013.

23. Abramovitz L, Rubinek T, Ligumsky H, Bose S, Barshack I, Avivi C, Kaufman B and Wolf I: KL1 internal repeat mediates Klotho tumor suppressor activities and inhibits bFGF and IGF-I signaling in pancreatic cancer. Clin Cancer Res 17: 4254-4266, 2011.

24. Rubinek T, Shulman M, Israeli S, Bose S, Avraham A, Zundelevich A, Evron E, Gal-Yam EN, Kaufman B and Wolf I: Epigenetic silencing of the tumor suppressor Klotho in human breast cancer. Breast Cancer Res Treat 133: 649-657, 2012.

25. Wolf I, Levanon-Cohen S, Bose S, Ligumsky H, Sredni B, Kanety H, Kuro-o M, Karlan B, Kaufman B, Koeffler HP and Rubinek T: Klotho: A tumor suppressor and a modulator of the IGF-1 and FGF pathways in human breast cancer. Oncogene 27: 7094-7105, 2008.

26. Doi S, Zou Y, Togao O, Pastor JV, John GB, Wang L, Shiizaki K, Gotschall R, Schiavi S, Yorioka N, et al: Klotho inhibits transforming growth factor-betal (TGF-betal) signaling and suppresses renal fibrosis and cancer metastasis in mice. J Biol Chem 286: 8655-8665, 2011.

27. Tang X, Fan Z, Wang Y, Ji G, Wang M, Lin J and Huang S: Expression of Klotho and $\beta$-catenin in esophageal squamous cell carcinoma, and their clinicopathological and prognostic significance. Dis Esophagus 29: 207-214, 2016.

28. Tang X, Wang Y, Fan Z, Ji G, Wang M, Lin J, Huang S and Meltzer SJ: Klotho: A tumor suppressor and modulator of the Wnt/ $\beta$-catenin pathway in human hepatocellular carcinoma. Lab Invest 96: 197-205, 2016.

29. Lee J, Jeong DJ, Kim J, Lee S, Park JH, Chang B, Jung SI, Yi L, Han Y, Yang Y, et al: The anti-aging gene Klotho is a novel target for epigenetic silencing in human cervical carcinoma. Mol Cancer 9: 109, 2010.

30. Usuda J, Ichinose S, Ishizumi T, Ohtani K, Inoue T, Saju H, Kakihana M, Kajiwara N, Uchida O, Nomura M, et al: Klotho is a novel biomarker for good survival in resected large cell neuroendocrine carcinoma of the lung. Lung Cancer 72: 355-359, 2011.

31. Yan Y, Wang Y, Xiong Y, Lin X, Zhou P and Chen Z: Reduced Klotho expression contributes to poor survival rates in human patients with ovarian cancer, and overexpression of Klotho inhibits the progression of ovarian cancer partly via the inhibition of systemic inflammation in nude mice. Mol Med Rep 15: 1777-1785, 2017.

32. Kim JH, Hwang KH, Lkhagvadorj S, Jung JH, Chung HC, Park HS, Kong ID, Eom M and Cha SK: Klotho plays a critical role in clear cell renal cell carcinoma progression and clinical outcome. Korean J Physiol Pharmacol 20: 297-304, 2016.

33. Li XX, Huang LY, Peng JJ, Liang L, Shi DB, Zheng HT and Cai SJ: Klotho suppresses growth and invasion of colon cancer cells through inhibition of IGF1R-mediated PI3K/AKT pathway. Int J Oncol 45: 611-618, 2014

34. Seo M, Kim MS, Jang A, Chung HJ, Noh Y, Kim DH, Lee J, Ko K and Myung SC: Epigenetic suppression of the anti-aging gene Klotho in human prostate cancer cell lines. Anim Cells Syst (Seoul) 21: 223-232, 2017

35. Kusaba T, Okigaki M, Matui A, Murakami M, Ishikawa K, Kimura T, Sonomura K, Adachi Y, Shibuya M, Shirayama T, et al: Klotho is associated with VEGF receptor-2 and the transient receptor potential canonical-1 $\mathrm{Ca} 2+$ channel to maintain endothelial integrity. Proc Natl Acad Sci USA 107: 19308-19313, 2010.

36. Galkina $\mathrm{E}$ and Ley $\mathrm{K}$ : Vascular adhesion molecules in atherosclerosis. Arterioscler Thromb Vasc Biol 27: 2292-2301, 2007.

37. Maekawa Y, Ishikawa K, Yasuda O, Oguro R, Hanasaki H, Kida I, Takemura Y, Ohishi M, Katsuya T and Rakugi H: Klotho suppresses TNF-alpha-induced expression of adhesion molecules in the endothelium and attenuates NF-kappaB activation. Endocrine 35: 341-346, 2009.

38. Xie B, Zhou J, Shu G, Liu DC, Zhou J, Chen J and Yuan L: Restoration of Klotho gene expression induces apoptosis and autophagy in gastric cancer cells: Tumor suppressive role of Klotho in gastric cancer. Cancer Cell Int 13: 18, 2013.

39. Shu G, Xie B, Ren F, Liu DC, Zhou J, Li Q, Chen J, Yuan L and Zhou J: Restoration of Klotho expression induces apoptosis and autophagy in hepatocellular carcinoma cells. Cell Oncol (Dordr) 36: 121-129, 2013. 
40. Dalton GD, Xie J, An SW and Huang CL: New insights into the mechanism of action of soluble Klotho. Front Endocrinol (Lausanne) 8: 323, 2017.

41. Mencke R, Olauson H and Hillebrands JL: Effects of Klotho on fibrosis and cancer: A renal focus on mechanisms and therapeutic strategies. Adv Drug Deliv Rev 121: 85-100, 2017.

42. Siegel RL, Miller KD and Jemal A: Cancer statistics, 2018. CA Cancer J Clin 68: 7-30, 2018.

43. Ferlay J, Soerjomataram I, Dikshit R, Eser S, Mathers C, Rebelo M, Parkin DM, Forman D and Bray F: Cancer incidence and mortality worldwide: Sources, methods and major patterns in GLOBOCAN 2012. Int J Cancer 136: E359-E386, 2015.

44. Siegel RL, Miller KD and Jemal A: Cancer statistics, 2020. CA Cancer J Clin 70: 7-30, 2020

45. Malhotra GK, Zhao X, Band H and Band V: Histological, molecular and functional subtypes of breast cancers. Cancer Biol Ther 10: 955-960, 2010.

46. Harbeck N, Thomssen C and Gnant M: St. Gallen 2013: Brief preliminary summary of the consensus discussion. Breast Care (Basel) 8: 102-109, 2013.

47. Akaza H: TNM classification. Nihon Hinyokika Gakkai Zasshi 85: 229-241, 1994 (In Japanese).

48. Brown RB and Razzaque MS: Phosphate toxicity and tumorigenesis. Biochim Biophys Acta Rev Cancer 1869: 303-309, 2018.

49. Ligumsky H, Rubinek T, Merenbakh-Lamin K, Yeheskel A, Sertchook R, Shahmoon S, Aviel-Ronen S and Wolf I: Tumor suppressor activity of Klotho in breast cancer is revealed by structure-function analysis. Mol Cancer Res 13: 1398-1407, 2015.

50. Trošt N, Peña-Llopis S, Koirala S, Stojan J, Potts PR, Fon Tacer K and Martinez ED: $\gamma$ Klotho is a novel marker and cell survival factor in a subset of triple negative breast cancers. Oncotarget 7 : 2611-2628, 2016

51. Untch M, Gerber B, Harbeck N, Jackisch C, Marschner N, Möbus V, von Minckwitz G, Loibl S, Beckmann MW, Blohmer JU, et al: 13th st. Gallen international breast cancer conference 2013: primary therapy of early breast cancer evidence, controversies, consensus-opinion of a german team of experts (Zurich 2013). Breast Care (Basel) 8: 221-229, 2013.

52. Dembinski TC, Leung CK and Shiu RP: Evidence for a novel pituitary factor that potentiates the mitogenic effect of estrogen in human breast cancer cells. Cancer Res 45: 3083-3089, 1985.

53. U.S National Library of Medicine (NIH): BLAST ${ }^{\circledR}$ : Basic local alignment search tool. National Center for Biotechnology Information, Bethesda, MD, 2021.

54. Livak KJ and Schmittgen TD: Analysis of relative gene expression data using real-time quantitative PCR and the 2(-Delta Delta C(T)) method. Methods 25: 402-408, 2001.

55. Ragab HM, Samy N, Afify M, El Maksoud NA and Shaaban HM: Assessment of $\mathrm{Ki}-67$ as a potential biomarker in patients with breast cancer. J Genet Eng Biotechnol 16: 479-484, 2018.

56. Park S, Park S, Kim J, Ahn S, Park KH and Lee H: Assessment of Ki-67 for predicting effective prognosis in breast cancer subtypes. Biomed Sci Lett 24: 9-14, 2018.

57. Colomer R, Aranda-López I, Albanell J, García-Caballero T, Ciruelos E, López-García MÂ, Cortés J, Rojo F, Martín M and Palacios-Calvo J: Biomarkers in breast cancer: A consensus statement by the Spanish society of medical oncology and the Spanish society of pathology. Clin Transl Oncol 20: 815-826, 2018

58. Kuro-o M: Klotho and aging. Biochim Biophys Acta 1790: 1049-1058, 2009.

59. Kuro-o M: Klotho in health and disease. Curr Opin Nephrol Hypertens 21: 362-368, 2012

60. Arbel Rubinstein T, Shahmoon S, Zigmond E, Etan T, Merenbakh-Lamin K, Pasmanik-Chor M, Har-Zahav G, Barshack I, Vainer GW, Skalka N, et al: Klotho suppresses colorectal cancer through modulation of the unfolded protein response. Oncogene 38: 794-807, 2019.

61. Chang B, Kim J, Jeong D, Jeong Y, Jeon S, Jung SI, Yang Y Kim KI, Lim JS, Kim C and Lee MS: Klotho inhibits the capacity of cell migration and invasion in cervical cancer. Oncol Rep 28: 1022-1028, 2012

62. Sopjani M, Rinnerthaler M, Kruja J and Dermaku-Sopjani M: Intracellular Signaling of the aging suppressor protein Klotho Curr Mol Med 15: 27-37, 2015.

63. Pako J, Bikov A, Barta I, Matsueda H, Puskas R, Galffy G, Kerpel-Fronius A, Antus B and Horvath I: Assessment of the circulating Klotho protein in lung cancer patients. Pathol Oncol Res 26: 233-238, 2020.
64. Oh HJ, Oh H, Nam BY, You JS, Ryu DR, Kang SW and Chung YE: The protective effect of Klotho against contrast-associated acute kidney injury via the antioxidative effect. Am J Physiol Renal Physiol 317: F881-F889, 2019.

65. Brominska B, Gabryel P, Jarmolowska-Jurczyszyn D, Janicka-Jedyńska M, Kluk A, Trojanowski T, Brajer-Luftmann B, Woliński K, Czepczyński R, Gut P, et al: Klotho expression and nodal involvement as predictive factors for large cell lung carcinoma. Arch Med Sci 15: 1010-1016, 2019.

66. Soliman NA and Yussif SM: Ki-67 as a prognostic marker according to breast cancer molecular subtype. Cancer Biol Med 13: 496-504, 2016.

67. Inwald EC, Klinkhammer-Schalke M, Hofstädter F, Zeman F, Koller M, Gerstenhauer M and Ortmann O: Ki-67 is a prognostic parameter in breast cancer patients: Results of a large population-based cohort of a cancer registry. Breast Cancer Res Treat 139: 539-552, 2013

68. Wu Q, Ma Q, Deng Y, Luo W, Zhao Y, Li W and Zhou Q: Prognostic value of ki-67 in patients with resected triple-negative breast cancer: A meta-analysis. Front Oncol 9: 1068, 2019.

69. Bruey JM, Kantarjian H, Estrov Z, Zhang Z, Ma W, Albitar F, Abdool A, Thomas D, Yeh C, O'Brien S and Albitar M: Circulating $\mathrm{Ki}-67$ protein in plasma as a biomarker and prognostic indicator of acute lymphoblastic leukemia. Leuk Res 34: 173-176, 2010.

70. Goldhirsch A, Wood WC, Coates AS, Gelber RD, Thürlimann B and Senn HJ; Panel members: Strategies for subtypes-dealing with the diversity of breast cancer: Highlights of the St. Gallen international expert consensus on the primary therapy of early breast cancer 2011. Ann Oncol 22: 1736-1747, 2011.

71. Varga Z, Diebold J, Dommann-Scherrer C, Frick H, Kaup D, Noske A, Obermann E, Ohlschlegel C, Padberg B, Rakozy $\mathrm{C}$, et al: How reliable is Ki-67 immunohistochemistry in grade 2 breast carcinomas? A QA study of the Swiss working group of breast- and gynecopathologists. PLoS One 7: e37379, 2012.

72. Polley MY, Leung SC, McShane LM, Gao D, Hugh JC, Mastropasqua MG, Viale G, Zabaglo LA, Penault-Llorca F, Bartlett JM, et al: An international ki67 reproducibility study. J Natl Cancer Inst 105: 1897-1906, 2013.

73. Jonat $\mathrm{W}$ and Arnold $\mathrm{N}$ : Is the Ki-67 labelling index ready for clinical use? Ann Oncol 22: 500-502, 2011.

74. Gudlaugsson E, Skaland I, Janssen EA, Smaaland R, Shao Z, Malpica A, Voorhorst F and Baak JP: Comparison of the effect of different techniques for measurement of Ki67 proliferation on reproducibility and prognosis prediction accuracy in breast cancer. Histopathology 61: 1134-1144, 2012.

75. Mikami Y, Ueno T, Yoshimura K, Tsuda H, Kurosumi M, Masuda S, Horii R, Toi $M$ and Sasano H: Interobserver concordance of Ki67 labeling index in breast cancer: Japan breast cancer research group Ki67 ring study. Cancer Sci 104: $1539-1543,2013$

76. Christopoulos PF, Msaouel P and Koutsilieris M: The role of the insulin-like growth factor-1 system in breast cancer. Mol Cancer 14: 43, 2015

77. Oloomi M, Moazzezy N and Bouzari S: Comparing blood versus tissue-based biomarkers expression in breast cancer patients. Heliyon 6: e03728, 2020

78. Diniz RW, Guerra MR, Cintra JR, Fayer VA and Teixeira MT: Disease-free survival in patients with non-metastatic breast cancer. Rev Assoc Med Bras (1992) 62: 407-413, 2016.

79. Li X, Yang J, Peng L, Sahin AA, Huo L, Ward KC, O'Regan R, Torres MA and Meisel JL: Triple-negative breast cancer has worse overall survival and cause-specific survival than non-triple-negative breast cancer. Breast Cancer Res Treat 161 279-287, 2017.

80. Carter CL, Allen C and Henson DE: Relation of tumor size, lymph node status, and survival in 24,740 breast cancer cases. Cancer 63: 181-187, 1989.

81. Dai X, Li Y, Bai Z and Tang XQ: Molecular portraits revealing the heterogeneity of breast tumor subtypes defined using immunohistochemistry markers. Sci Rep 5: 14499, 2015.

82. Usuda J, Ichinose S, Ishizumi T, Ohtani K, Inoue T, Saji H, Kakihana M, Kajiwara N, Uchida O, Nomura M, et al: Klotho predicts good clinical outcome in patients with limited-disease small cell lung cancer who received surgery. Lung Cancer 74 : 332-337, 2011.

83. Zhang J, Chen X, Shen L, Wang X, Wang L, Sun X and Qu S: The association between lymph node stage and clinical prognosis in thyroid cancer. Front Endocrinol (Lausanne) 11: 90, 2020. 
84. Nottegar A, Veronese N, Senthil M, Roumen RM, Stubbs B, Choi AH, Verheuvel NC, Solmi M, Pea A, Capelli P, et al: Extra-nodal extension of sentinel lymph node metastasis is a marker of poor prognosis in breast cancer patients: A systematic review and an exploratory meta-analysis. Eur J Surg Oncol 42: 919-925, 2016.

85. Li Y, Xiao H and Xue F: Overexpression of Klotho suppresses growth and pulmonary metastasis of osteosarcoma in vivo. Genet Mol Biol 43: e20190229, 2020.

86. Zhou X, Fang X, Jiang Y, Geng L, Li X, Li Y, Lu K, Li P, Lv $X$ and Wang $X$ : Klotho, an anti-aging gene, acts as a tumor suppressor and inhibitor of IGF-1R signaling in diffuse large B cell lymphoma. J Hematol Oncol 10: 37, 2017.

87. Lambert AW, Pattabiraman DR and Weinberg RA: Emerging biological principles of metastasis. Cell 168: 670-691, 2017.

88. Ruijtenberg S and van den Heuvel S: Coordinating cell proliferation and differentiation: Antagonism between cell cycle regulators and cell type-specific gene expression. Cell Cycle 15: 196-212, 2016.

89. Chen CD, Li H, Liang J, Hixson K, Zeldich E and Abraham CR The anti-aging and tumor suppressor protein Klotho enhances differentiation of a human oligodendrocytic hybrid cell line. J Mol Neurosci 55: 76-90, 2015.

90. Fan J and Sun Z: The antiaging gene Klotho regulates proliferation and differentiation of adipose-derived stem cells. Stem Cells 34: 1615-1625, 2016.

91. Ahrens HE, Huettemeister J, Schmidt M, Kaether C and von Maltzahn J: Klotho expression is a prerequisite for proper muscle stem cell function and regeneration of skeletal muscle. Skelet Muscle 8: 20, 2018.

92. Toan NK, Tai NC, Kim SA and Ahn SG: Soluble Klotho regulates bone differentiation by upregulating expression of the transcription factor EGR-1. FEBS Lett 594: 290-300, 2020.

93. Sárvári M, Kalló I, Hrabovszky E, Solymosi N, Rodolosse A, Vastagh C, Auer H and Liposits Z: Hippocampal gene expression is highly responsive to estradiol replacement in middle-aged female rats. Endocrinology 156: 2632-2645, 2015.
94. Lojkin I, Rubinek T, Orsulic S, Schwarzmann O, Karlan BY, Bose S and Wolf I: Reduced expression and growth inhibitory activity of the aging suppressor Klotho in epithelial ovarian cancer. Cancer Lett 362: 149-157, 2015.

95. Wolf I, Laitman Y, Rubinek T, Abramovitz L, Novikok I, Beeri R, Kuro-O M, Koeffler HP, Catane R, Freedman LS, et al: Functional variant of Klotho: A breast cancer risk modifier among BRCA1 mutation carriers of Ashkenazi origin. Oncogene 29: 26-33, 2010

96. Mahmoud AM, Al-Alem U, Ali MM and Bosland MC: Genistein increases estrogen receptor beta expression in prostate cancer via reducing its promoter methylation. J Steroid Biochem Mol Biol 152: 62-75, 2011.

97. Li Y, Chen F, Wei A, Bi F, Zhu X, Yin S, Lin W and Cao W: Klotho recovery by genistein via promoter histone acetylation and DNA demethylation mitigates renal fibrosis in mice. J Mol Med (Berl) 97: 541-552, 2019.

98. Oz OK, Hajibeigi A, Howard K, Cummins CL, van Abel M, Bindels RJ, Word RA, Kuro-o M, Pak CY and Zerwekh JE: Aromatase deficiency causes altered expression of molecules critical for calcium reabsorption in the kidneys of female mice * J Bone Miner Res 22: 1893-1902, 2007.

99. Carrillo-López N, Román-García P, Rodríguez-Rebollar A Fernández-Martín JL, Naves-Díaz M and Cannata-Andía JB: Indirect regulation of PTH by estrogens may require FGF23. J Am Soc Nephrol 20: 2009-2017, 2009.

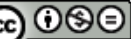

This work is licensed under a Creative Commons Attribution-NonCommercial-NoDerivatives 4.0 International (CC BY-NC-ND 4.0) License. 